\title{
Pengaruh Kualitas dan Kuantitas Pakan (Daun Bawang) terhadap Kejadian Polimorfisme Warna pada Larva Spodoptera exigua Hubner (Lepidoptera: Noctuidae)
}

\section{LATIZIO BENI DA COSTA CRUZ, I WAYAN SUPARTHA*), DAN I WAYAN SUSILA}

\author{
Program Studi Magister Pertanian Lahan Kering, Fakultas Pertanian, Universitas Udayana \\ Jl. P.B. Sudirman, Denpasar, Bali, 80232 \\ ${ }^{*}$ E-mail: yansupartha@yahoo.com
}

\begin{abstract}
The Effect of Feed (Onion Leaves) on the Event of Color Polymorphism on Larvae Spodoptera exigua HUBNER (Lepidoptera: Noctuidae). Color polymorphism is a form of color difference that appears morphologically and genetically in the same insect species. The existence of these changes in shape has to do with the defense mechanism of the species concerned for disguise, avoiding natural enemies and adjusting to the new environment. The occurrence of color polymorphism is often found in S. exigua larvae that attack the onion crop in the field. The purpose of the study was to determine the effect of the quality and quantity of feed (onion) on the color changes of S. exigua larvae. This research was carried out in the laboratory using adaptation test method and comparative test with randomized block design. The results of the study show that decreasing the quality and quantity of feed (onion) encourages color changes from green to dark. In addition, green to dark color changes are also triggered by the developmental phase of the larvae. The development of larvae from the 3rd instar phase has shown symptoms of color change from green to dark even though the quantity and quality of the food is fulfilled.
\end{abstract}

Keywords: Quality and quantity, food, polymorphism, S. exigua, Onion

\section{PENDAHULUAN}

Spodoptera exigua merupakan salah satu hama utama pada tanaman bawang yang dapat merusak tanaman mencapai $100 \%$ dan dapat menyerang sepanjang tahun baik musim kemarau maupun musim hujan (Negara, 2003). Larva S. exigua biasanya melakukan perubahan warna atau biasa disebut polimorfisme warna pada fase larvanya. Polimorfisme warna merupakan dua atau lebih perbedaan warna secara morfologi dan genetik dalam spesies yang sama dengan melakukan kopulasi tunggal yang tinggi semata-mata untuk menaikkan frekuensinya yang kebetulan berlangsung berulang kali (Gray dan Mc. Kinnon 2007).

Menurut Hedrick (2006) Perubahan warna pada serangga pertama kali mengadopsi pola warna pada morfologi tanaman seperti daun, ranting dan kulit 


\section{LATIZIO BENI DA COSTA CRUZ. et al. Pengaruh Kualitas dan Kuantitas Pakan...}

batang, terjadinya perubahan warna pada larva bertujuan untuk menghindari dari musuh alaminya, melakukan pengelola makanan dan menyesuaikan diri dengan lingkungan baru. Jumlah perubahan warna pada satu spesies serangga berkisar antara 34 dan ada juga yang sampai puluhan warna seperti pada belalang belal (Acrydium arenosum), siput darat (Cepaea nemoralis), kupu-kupu (Catocala micronympha) (Bond 2007).

Sampai saat ini belum ada laporan yang rinci menengenai kejadian polimorfisme pada ulat grayak yang berada pada tanaman bawang terutama berkaitan dengan status hama tersebut sebagai hama tanaman bawang di lapang. Oleh karena itu perlu melakukan penelitian mengenai pengaruh kualitas dan kuantitas pakan terhadap polimorfisme warna pada larva Spodoptera exigua. Tujuan dari penelitian ini adalah (1) untuk mengetahui pengaruh kualitas dan kuantitas pakan (daun bawang) terhadap perubahan warna larva $S$. exigua.

\section{METODE PENELITIAN}

Penelitian

dilaksanakan

di

Laboratorium Pengendalian Hama Terpadu (IPM Lab) Fakultas Pertanian, Universitas Udayana. Penelitian berlangsung selama 3 bulan terhitung sejak Februari-April 2018.

Alat dan bahan yang digunakan dalam penelitian ini adalah: Larva $S$. xeigua, tanaman bawang, timbangan, kain kasa millar, preparat, gunting, kamera, dan alat tulis.

Sebelum melakukan penelitian Laboratorium langkah awal mempersiapkan bibit terlebih dahulu. Bibit bawang yang digunakan adalah bawang prei yang berasal dari penangkar benih di Desa Candikuning Kecamatan Baturiti Kabupaten Tabanan. Bibit tersebut kemudian ditanam langsung di lapang tujuannya untuk tetap mempertahankan kesegaran tanaman tersebut sehingga dapat tumbuh dengan baik sesuai dengan syarat tumbuhnya. Tanaman yang digunakan untuk penelitian ini adalah tanaman berumur 2, 5 dan 8 minggu setelah tanam. Metode yang digunakan untuk penelitian di Laboratorium adalah metode uji adaptasi dan uji komparasi dengan menggunakan rancangan acak kelompok.

\section{Percobaan kualitas pakan terhadap perubahan larva warna hijau dan gelap}

Percobaan ini bertujuan untuk melihat perubahan warna dari larva warna hijau ke gelap dan dari larva warna gelap ke hijau dengan menggunakan daun bawang prei umur 2 MST, 5 MST dan 8 MST. Caranya adalah kedalam 3 stoples plastik transparan dengan diameter $15 \mathrm{~cm}$ dan tinggi $10 \mathrm{~cm}$ masing-masing diletakkan daun bawang prei umur 2 MST, 5 MST dan 8 MST. Selanjutnya ke masing-masing stoples diinfestasikan 1 larva instar 3 warna hijau lalu ditutup dengan kain milar. Setelah 24 jam diamati perubahan warna larva. Penelitian ini diulang 10 kali sehingga diperlukan 30 larva instar 3. Percobaan yang sama juga dilakukan terhadap larva warna gelap (Gambar 1). 


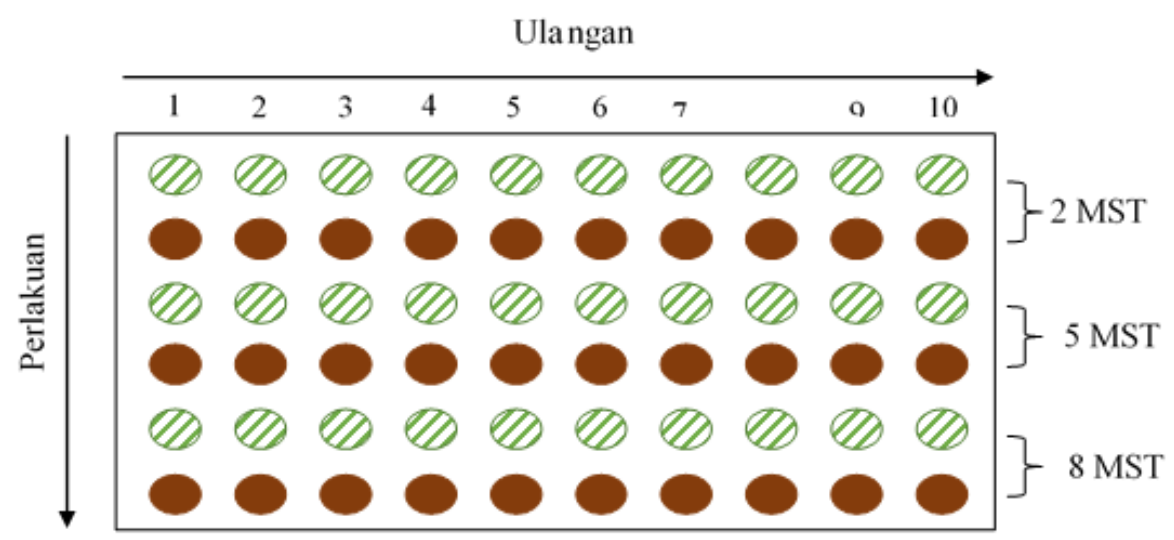

Gambar 1. Bagan percobaan kualitas pakan dan megetahui efisiensi makan antara larva warna hijau dan gelap

\section{Keterangan : $\oslash$ : Larva warna hijau \\ : Larva warna gelap}

Percobaan kuantitas pakan terhadap 5 diletakkan $1.25 \mathrm{~g}$, dan kedalam stoples 6 perubahan larva warna hijau dan gelap.

Percobaan ini bertujuan untuk prei sebagai kontrol. Selain itu kedalam mengetahui pengaruh kuantitas pakan masing-masing stoples diletakan tissue yang terhadap perubahan warna larva dari hijau ke dibasahi dengan air. Pengamatan dilakukan gelap. Caranya adalah kedalam stoples 1 yangtransparan dengan diameter $15 \mathrm{~cm}$ dan tinggi $10 \mathrm{~cm}$ yang sudah berisi 1 larva instar 3 diletakkan $0.25 \mathrm{~g}$ daun bawang prei umur 5 setiap 24 jam setelah perlakuan sampai semua larva warna hijau berubah menjadi warna gelap. Percobaan ini diulang sebanyak MST, kedalam stoples 2 diletakan $0.50 \mathrm{~g}$, kedalam stoples 3 diletakan $0.75 \mathrm{~g}$, kedalam stoples 4 diletakkan $1.00 \mathrm{~g}$, kedalam stoples 7 kali sehingga diperlukan 42 larva instar 3 warna hijau (Gambar 2). Percobaan yang sama dilakukan dengan menggunakan larva instar 4 .

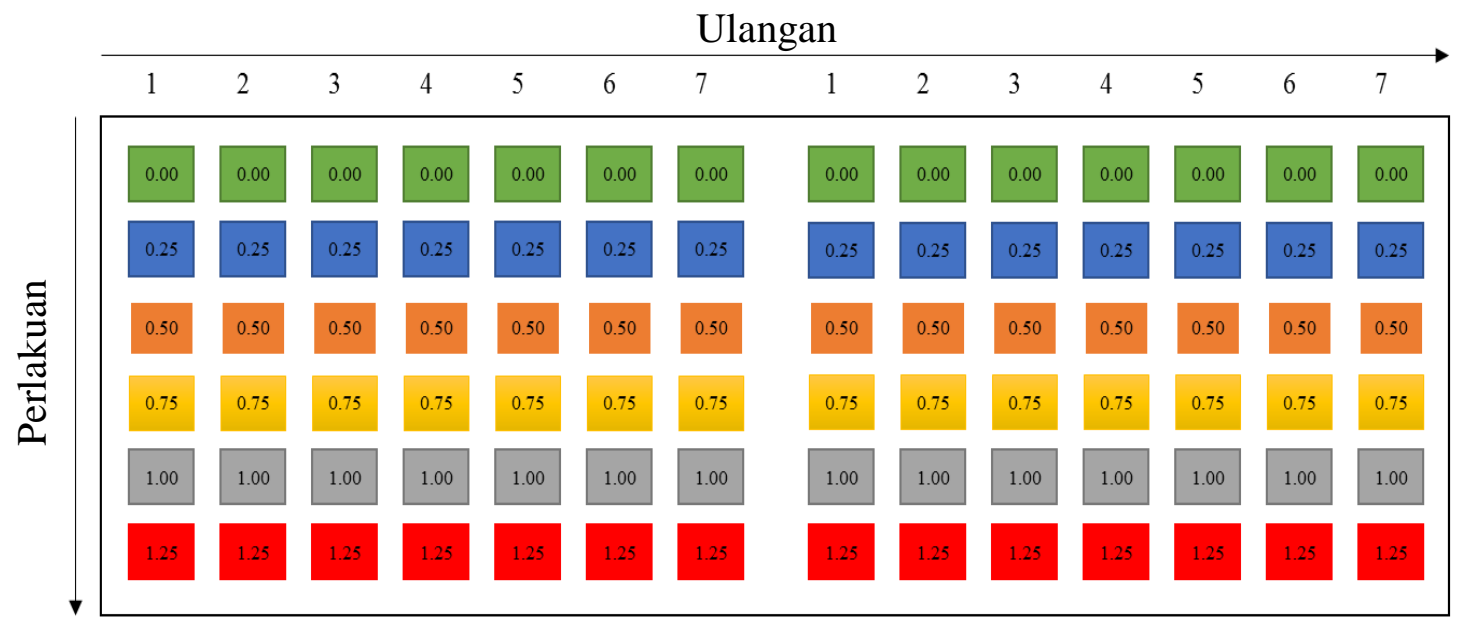

Gambar 2. Bagan Uji kuantitas tanaman terhadap larva warna hijau 


\section{LATIZIO BENI DA COSTA CRUZ. et al. Pengaruh Kualitas dan Kuantitas Pakan...}

\begin{tabular}{l|l|l} 
Keterangan : & 0.00 & $=0.00 \mathrm{~g}$ \\
& 0.75 & $=0.75 \mathrm{~g}$
\end{tabular}

\section{Analisis Data}

Untuk melihat perbedaan efisiensi makan menggunakan analisa sidik ragam (ANOVA) dan bila menunjukkan perbedaan yang nyata maka dilanjutkan dengan uji Duncans 5\% (Zar 1996). Hasil penelitian disajikan dalam bentuk tabel dan gambar.

\section{HASIL DAN PEMBAHASAN}

\section{Pengaruh kualitas pakan terhadap} perubahan warna larva $S$. exigua.

Percobaan kualitas pakan (daun bawang) yang dipetik pada tanaman bawang umur berbeda kemudian diberi makan pada larva S. exigua warna hijau dan gelap menunjukkan bahwa terjadi perubahan warna yang sangat signifikan ditunjukkan oleh larva warna hijau menjadi gelap sedangkan larva warna gelap tidak melakukan perubahan warna ke hijau. Larva warna hijau mulai melakukan perubahan warna menjadi gelap pada hari ke 1 (satu) setelah diberi makan.

Apabila dilihat dari persentase tertinggi ditunjukkan oleh larva yang diberi makan dengan perlakuan daun tanaman berumur 8 MST (80\%) kemudian diikuti oleh larva yang diberi makan dengan perlakuan daun tanaman umur 5 MST (10\%) dan terendah pada perlakuan daun tanaman umur 2 MST karena tidak melakukan perubahan warna pada 1(satu) hari setelah diberi makan. Larva warna hijau dengan perlakuan daun tanaman 2 MST mulai melakukan perubahan warna (10\%) pada hari ke 2 (dua) setelah diberi makan sedangkan pada waktu tersebut larva warna hijau pada pakan 8 MST sudah melakukan perubahan warna (100\%) menjadi warna gelap. Larva warna hijau pada pakan 2 dan 5 mts mulai melakukan perubahan keseluruhan (100\%) pada hari ke 4 setelah diberi makan (Gambar 3).

Peristiwa ini sesuai dengan hasil penelitian Moscardi, et al. (1981) menyebutkan bahwa larva Anticarsia gemmatalis melakukan perubahan warna dari hijau ke hitam pada saat larva dilapang meningkat dan dipengaruhi juga oleh umur tanaman yang merupakan salah satu faktor penting yang mempengaruhi kualitas nutris makanan yang menurun pada saat tanaman memasuki fase generatif. Penampilan warna larva dipengaruhi oleh lamanya waktu larva diberi makan dengan makanan tertentu. Hal Ini menunjukkan bahwa larva dapat mengubah warna dengan mengganti pola makan selama hidupnya.

Plastisitas ini dalam mengubah warna tubuh dapat melengkapi perubahan dalam perilaku makan larva, seperti perubahan fase pada tanaman inang (Zalucki, et al.1986; Johnson dan Zalucki 2007). Hasil penelitian Yamasaki, et al. (2009) mengenai perubahan warna larva Helicoverpa armigera tergantung pada nilai gizi yang terkandung di dakam makanan yang dikonsumsi. Apabila kandungan nutrisi di dalam suatu pakan sesuai dengan kebutuhan larva, maka biasanya larva cenderung berwarna hijau dan sebaliknya apabila nutrisi pada pakan tidak sesuai dengan kebutuhan larva $H$. armigera maka warna yang ditampilkan oleh larva tersebut berwarna coklat kehitaman. 
Hasil penelitian Ramos dan MoralloRejesus (1976) meyatakan bahwa warna larva $H$. armigera, terutama garis memanjang dan bintik-bintik lateral, sebagian besar dipengaruhi oleh pigmen tumbuhan, terutama kandungan karoten yang berasal dari makanan yang di komsumsi. Peristiwa ini sesuai dengan hasil penelitian Sunarto, et al. (2005) menyebutkan bahwa pemenuhan kebutuhan nutrisi tanaman menentukan kelangsungan hidup serangga seperti pergantian kulit, pertambahan tubuh yaitu berat dan panjang juga reproduksi. Salah satu contoh Spodoptera exempta mempunyai kemampuan untuk melakukan seleksi makan. Kemampuan dari S. exempta memilih makanan bukan berdasarkan rasa melainkan berdasarkan kandungan nutrisinya (Ahmad dan Kamal 2001).

Kejadian ini sesuai dengan yang ditunjukkan oleh larva $S$. exigua dimana lebih memilih tanaman yang memiliki kandungan nutrisi yang sesuai dengan yang dibutuhkan seperti pada perlakuan tanaman umur dua minggu dimana tanaman tersebut memiliki kadar air dan protein yang cukup dan tingkat kekerasan daun tanaman yang tidak terlalu keras seperti pada daun tanaman delapan minggu setelah tanam.

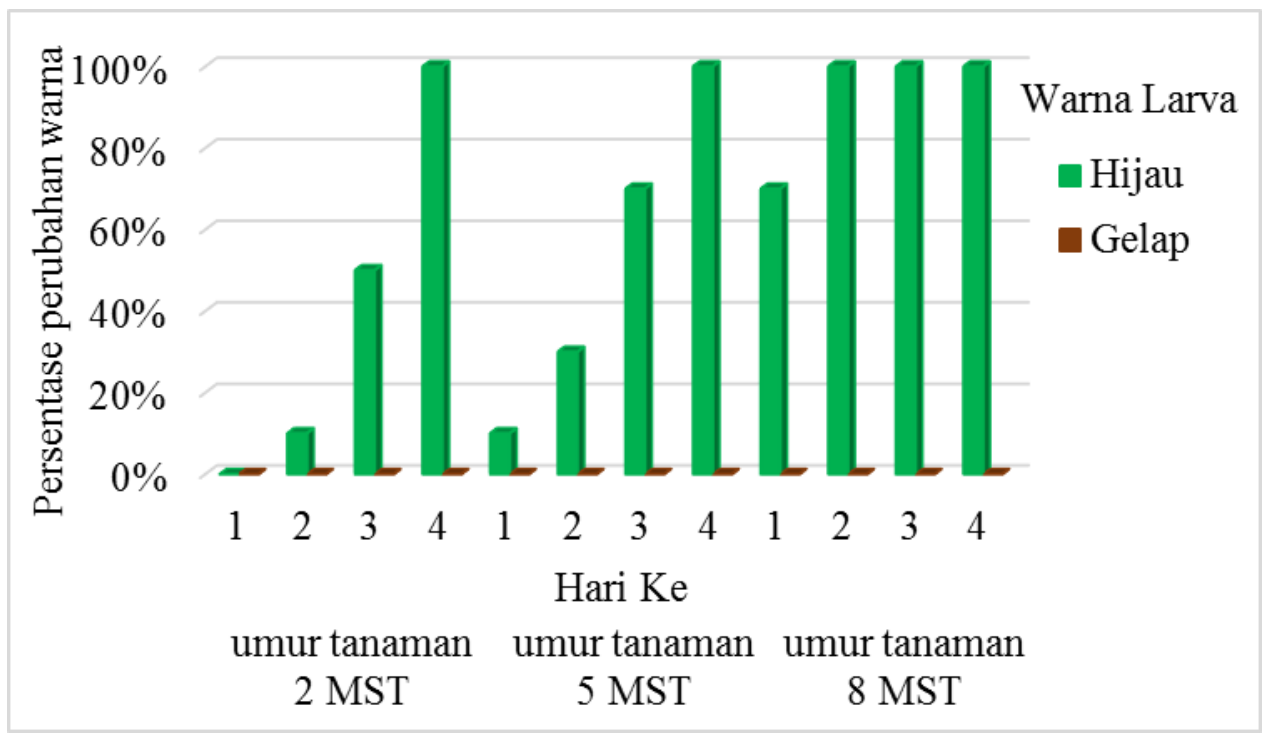

Gambar 3. Perubahan warna larva S. exigua dari hijau menjadi gelap dan dari warna gelap menjadi hijau pada hari ke 1-4 dengan uji umur tanaman yang berbeda (2, 5, dan 8 MST).

Pengaruh kuantitas pakan terhadap juga dapan mempengaruhi terjadinya perubahan warna larva $S$. exigua.

Hasil percobaan kuantitas pakan (Kontrol (0), 0.25, 0.50, 0.75, 1.00, $1.25 \mathrm{~g}$ daun bawang) terhadap perubahan warna larva $S$. exigua instar 3 dan 4 dari hijau menjadi gelap dengan ulangan sebanyak 7 kali menunjukkan bahwa kekurangan makan polimorfisme warna dari hijau ke gelap. Perubahan warna larva $S$. exigua intar 3 dan 4 sudah terjadi pada hari ke 1(satu) setelah pemberian makan. Larva S. exigua intar 3 melakukan perubahan warna tertinggi pada perlakuan $0 \mathrm{~g}(71 \%)$ diikuti oleh perlakuan $0.25 \mathrm{~g}(57 \%)$ dan perlakuan $0.50 \mathrm{~g}(29 \%)$, 


\section{LATIZIO BENI DA COSTA CRUZ. et al. Pengaruh Kualitas dan Kuantitas Pakan...}

sedangkan terendah ditunjukkan pada perlakuan $(0.75,1.00$ dan $1.25 \mathrm{~g})$ sebab tidak melakukan perubahan warna. Perlakuan 0.75 $\mathrm{g}$ dan $1.0 \mathrm{~g}$ baru melakukan perubahan warna pada pada hari ke 2 (dua) setelah diberi makan dengan persentase (43\% dan 14\%) sedangkan perlakuan $1.25 \mathrm{~g}$ mulai melakukan perubahan warna pada hari ke 3 setelah diberi makan (43\%).

Larva S. exigua instar 4 melakukan perubahan warna tertinggi ditunjukkan pada perlakuan 0.00 dan $0.25 \mathrm{~g}(59 \%)$ diikuti oleh perlakuan $0.50(29 \%)$ kemudia perlakuan $0.75 \mathrm{~g}(14 \%)$ dan terendah ditunjukkan pada perlakuan $1.00 \mathrm{~g}$ dan $1.25 \mathrm{~g}$ karena tidak melakukan perubahan pada hari 1 (satu) setelah diberi makan. Perlakuan $1.0 \mathrm{~g}$ dan $1.25 \mathrm{~g}$ mulai melakukan perubahan warna pada hari ke 2 (dua) setelah diberi makan dengan persentase $43 \%$ dan $14 \%$. Perubahan warna secara keseluruhan (100\%) oleh kedua instar tersebut terjadi pada hari ke 4 (empat) setelah diberi makan (Gambar 4).

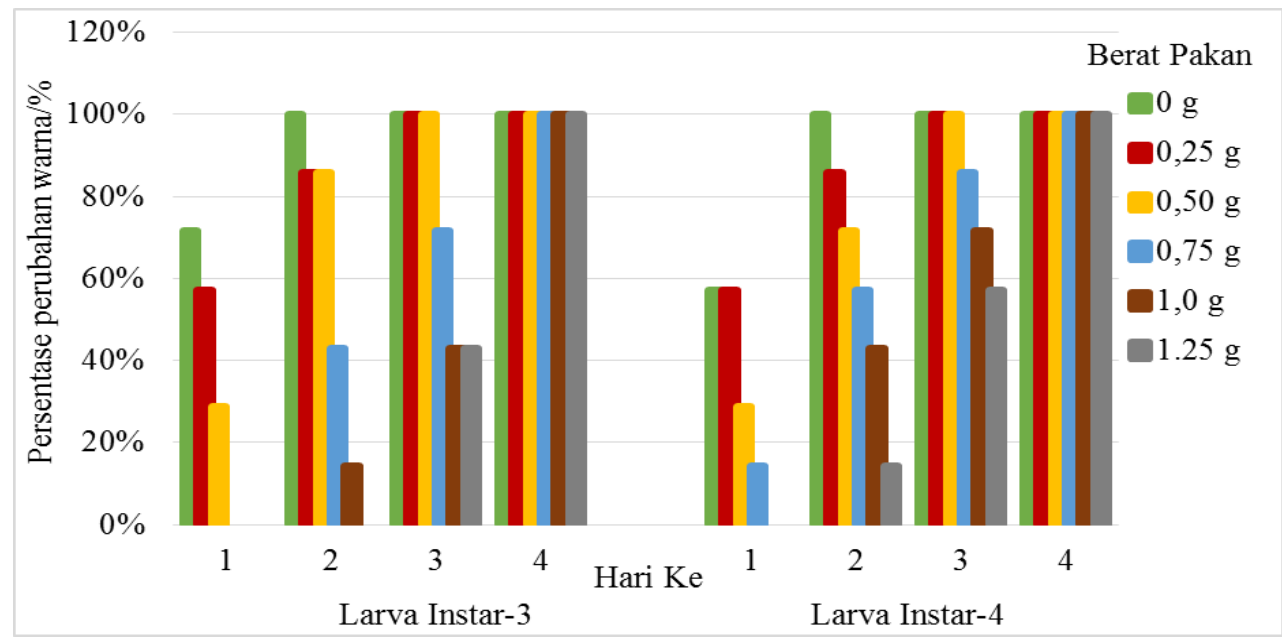

Gambar 4. Perubahan warna larva S. exigua instar 3 dan 4 dari hijau menjadi gelap pada hari ke 1-4 dengan uji berat pakan yang berbeda $(0,0.25,0.50,0.75,1.0$, dan 1.25$)$.

Kejadian ini sesuai dengan hasil penelitian Ramos dan Morallo-Rejesus (1976) menyatakan bahwa serangga Lepidoptera seperti larva $H$. armigera biasanya melakukan pengelola makan pada saat tanaman inang yang berada di habitatnya tidak tercukupi atau berkurang, pada saat pengelolaan makan tersebut bisanya larva dari $H$. armigera melakukan perubahan warna dari hijau menjadi coklat muda sampai coklat kehitaman. Hasil penelitian Van Der Geest (1968) menyatakan bahwa larva Pieris brassicae juga menunjukkan warna yang berbeda ketika dipelihara pada berat pakan yang berbeda. Larva $P$. brassicae yang diberi makan dengan berat medium akan memiliki warna kuning kehitaman dibandingkan larva yang diberi makan maksimum cenderum berwarna hijau kekuningan.

Pengujian di Laboratorium hanya sampai 4 hari dikarenakan pada waktu itu semua larva sudah melakukan perubahan warna. Salah satu pemicunya adalah perkembangan fase dari larva $S$. exigua. 
Kalshoven (1981) menyatakan bahwa larva hitaman pada bagian abdomen, pada S. exigua memiliki variasi warna, larva instar abdomen terdapat garis hitam yang satu biasanya berwarna hijau muda, melintang. Pada saat larva memasuki instar kemudian berubah menjadi hijau tua saat lima warnanya berubah menjadi coklat muda memasuki instar dua. Pada larva instar tiga sampai coklat kehitaman (Gambar 5). dan empat warnanya menjadi hijau kehitam-

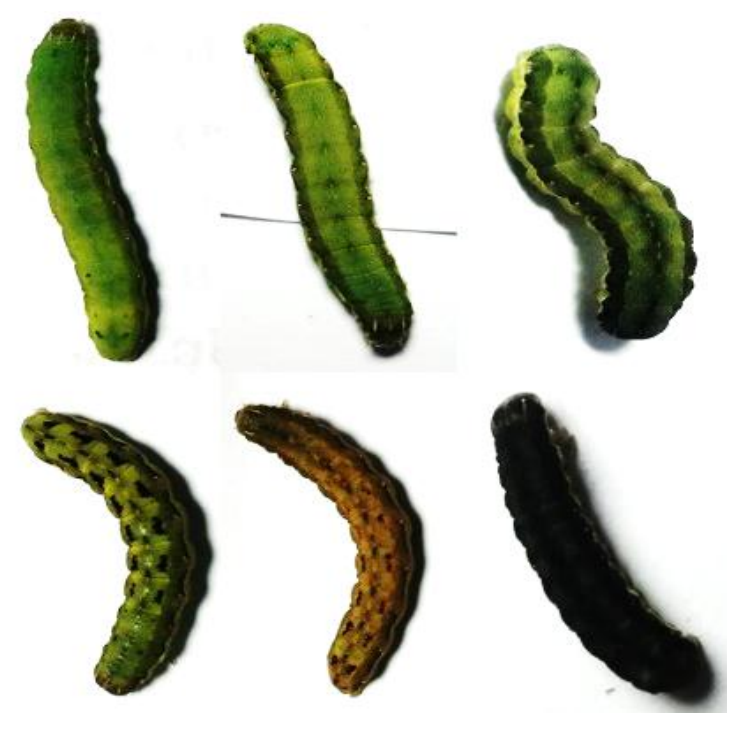

Gambar 5. Tahapan perubahan larva instar 3 S. exigua dari warna hijau menjadi gelap

\section{SIMPULAN}

Penurunan kuantitas dan kualitas makanan mendorong terjadinya perubahan warna dari hijau ke gelap. Selain itu perubahan warna hijau ke warna gelap juga dipicu oleh adanya fase perkembangan larva. Perkembangan larva mulai fase instar 3 sudah menunjukkan gejala perubahan warna tersebut dari hijau ke gelap walaupun kuantitas dan kualitas makanannya terpenuhi.

\section{DAFTAR PUSTAKA}

Ahmad, I. and Kamal, M. 2001. Consumption and Utilization of Complete Defined Diets Containing Various Carbohydrate by Spodoptera exempta (Lepidoptera; Noctuidae). BIOTA 4 (3): 99-104.

Bond, A.B. 2007. The Evolution of Color Polymorphism: Crypticity, Searching Images, and Apostatic Selection. Faculty Publications in the Biological Sciences. 52: 489-514

Gray, S.M., and McKinnon, J.S. 2007. Linking color polymorphism maintenance and speciation. Trends Ecol Evol. 22 (2):71-79

Hedrick, P.W. 2006. Genetic polymorphism in heterogeneous environments: the age of genomics. Annu. Rev. Ecol. Evol. Syst. 37:67-93

Johnson, M. L., and M. P. Zalucki. 2007. Feeding and Foraging Behavior of a generalist caterpillar: are third instars 


\section{LATIZIO BENI DA COSTA CRUZ. et al. Pengaruh Kualitas dan Kuantitas Pakan...}

are just bigger versions of Prsts? Bull. Entomol. Res. 97: 81-88.

Kalshoven, L.G.E., 1981. Pest of Crops in Indonesia. Rev. By Van Der Laan. Ichtiar Bani - Van Boeve, Jakarta.

Moscardi, F., C. S. Barfield, \& G. E. Allen. 1981. Consumption and development of velvetbean caterpillar as influenced by soybean phenology. Environ. Entomol. 10: 880-884.

Negara, A. 2003. Penggunaan Analisis Probit Untuk Pendugaan Tingkat Populasi Spodoptera exigua Terhadap Deltametrin Di Daerah Istimewa Yogyakarta. Jurnal Informatika Pertanian 1 (2): 1-9.

Ramos, V. E., and B. Morallo-Rejesus. 1976. Effects of nutrition on larval coloration of Helicoverpa armigera (Hubner). Philipp. J. Entomol. 3: 201-224.

Sunarto, D. A, Sulistyowati, E, dan Sujak. 2005 Pengaruh Galur Harapan Kapas
Terhadap Beberapa Aspek Biologi Ulat Penggerek Buah Helicoverpa armigera (Hubner) Lepidoptera: Noctuidae). Jurnal Litri

Van Der Geest, L.P.S. 1968. Effect of diets on the haemolymph proteins of larvae of Pieris brassicae. J. Insect Physiol. 14: 537-542.

Yamasaki, A., Shimizu and Fujisaki, K. 2009. Effect of Host Plant Part on Larval Body-Color Polymorphism in Helicoverpa armigera (Lepidoptera: Noctuidae). Ann. Entomol. Soc. Am. 102(1): 76-84

Zalucki, M. P., G. Daglish, S. Firempong, and P. H. Twine. 1986. The biology and ecology of Heliothis armigera (Hubner) and $H$. punctigera Wallengren (Lepidoptera: Noctuidae) in Australia: what do we know? Aust. J. Zool. 34: 779-814 